\title{
DOPPELGANGERS SIBLINGS IN THE KITE RUNNER
}

Muhammad Hanif ${ }^{1}$, Shaista Shahzadi ${ }^{2 *}$, Rao Akmal Ali $^{3}$, Asmat A. Sheikh ${ }^{4}$

${ }^{1}$ Lecturer, COMSATS Vehari, Pakistan; ${ }^{2 * 3}$ Lecturer, NUML, Multan, Pakistan; ${ }^{4}$ Assoicate Professor, The Women

University, Multan, Pakistan.

Email: ${ }^{1}$ muhammadhanif@ciitvehari.edu.pk, ${ }^{2 *}$ shahzadi.shaista@yahoo.com

Article History: Received on $13^{\text {th }}$ February 2021, Revised on $30^{\text {th }}$ May 2021, Published on $10^{\text {th }}$ June 2021

\section{Abstract}

Purpose of the study: This study analyses the novel The Kite Runner (2007) of Khaled Hosseini in the light of the concept of mirror images given by Sigmund Freud in The Uncanny (1919). Bearing in mind Freud's conjecture, this inquiry enroots some personalities who have similar features and qualities.

Methodology: This study is qualitative in nature. The Kite Runner is the first hand and chief source. While the second hand include easy and magazines about The Kite Runner. By concentrating on the notion of mirroring as given by Freud in The Uncanny. The study applies the concept of doppelganger siblings on Amir and Hassan, two main characters in the novel.

Main Findings: The findings show that Amir and Hassan are shown as doppelgangers of one another in this study. The two personalities have some same and some different qualities like a mirror image. This study sets Amir as Heimlich and Hassan is portrayed as Unhelmlich because Amir is rich and Hassan is poor.

Applications of this study: This research contributes to the field of doppelganger literature.

Novelty/Originality of this study: This study analyzes the doppelgangers in the kite runner and thus contributes to the long tradition of doppelganger in literature: The Picture of Dorian Gray, The Strange Case of Dr Jekyll and Mr Hyde and Frankenstein.

Keywords: Heimlich, Unheimlich, Doppelganger, Similarities, Characters.

\section{INTRODUCTION}

This study investigates the two chief personalities of The Kite Runner, as mirror images considering The Uncanny. Other studies have been made on the chief work including virtuous, communal and racial features of the Kite Runners. This study analyses that the mirror images are two mirror personalities that reflect the image of each other. As in the image, there is not any difference except the direction, same is the case in mirroring personalities as they merge into one another but they also have some differences. This study applies Freudian mirror images on the Kite Runner. It suggests the Mirroring theme: The Picture of Dorian Gray Strange case Dr. Jekyll and Mr. Hyde and Frankenstein to give evidence on the dialogues. The chief personalities of the crucial work will be judged with the personalities of these works to check whether these themes have many similarities. As good Dorain Gray, Dr. Jekyll and Dr. Trankenstein are Heimlich personalities in these respective Mr. Hyde and Frankenstein's monster are Unheimlich. So, this inquiry will compete for many features of these themes with the chief record.

The Freudian concept of doppelganger in The Uncanny is applied to the text: The Kite Runner. Freud describes the uncanny as a combination of Heimlich and unheimlich, where Heimlich means familiar, homely, and known while Unheimlich means unfamiliar, unhomely and unknown. Moreover, Heimlich also means something secretive, hidden, and mysterious. And, a doppelganger is an element of this uncanny where uncanny is the product of old and familiar, but repressed memories that are supposed to remain hidden but come to the surface (Masschelein, 2011). Thus, doppelgangers, like Heimlich and Unheimlich, are two characters that are as though mirror image of each other. As a mirror image looks exactly like the person but in the opposite direction so doppelganger characters get to mix up with each other while still having some differences.

This research applies Freudian doppelganger on The Kite Runner. It refers to the famous doppelganger works: The Picture of Dorian Gray, Strange Case of Dr. Jekyll and Mr. Hyde, and Frankenstein, to prove its arguments. The main characters of the main text will be compared with the characters of these works to check whether these works have any similarities. As, good-looking Dorian Gray, Dr. Jekyll, and Dr. Frankenstein are Heimlich characters in their respective works while heinous picture, Mr. Hyde and Frankenstein's monster are Unheimlich. So, this research will compare many aspects of these works with the main text.

The Kite Runner depicts the story of Amir while displaying the political situation of Afghanistan in the background. The narrator, Amir, tells the story of his childhood in Afghanistan. The story about his father, Baba, who was very authoritative, and the story of his best friend, Hassan. Moreover, the story of his adulthood in America of his romance, his experience of becoming a successful writer, and the struggles that he faces as an immigrant in America before becoming a successful writer. So, when Amir betrayed Hassan, he betrayed his own cultural identity. Amir's attempts at redemption are his attempts at regaining his own identity. As Murshida (2017) claims that: "Amir and Hassan grow up together and they complete each other with their skills". Thus, when Amir betrays Hassan, he betrays his own cultural identity in Afghanistan. Only after redeeming himself, he regains his Afghan identity. By this school of thought, this 
research attempts to establish that the two main characters of The Kite Runner are doppelgangers of each other. Doppelgangers are two characters who are each other's counterparts that have many similarities while still having some differences. Amir and Hassan played together in Kabul but are from different social backgrounds. They also have different character traits: Amir is caring but likes making fun of others while Hassan is kind and does not ridicule others. So, this study focuses on the similarities between these two characters by probing themes including religion, social class, ethnic groups, friendship, and brotherhood.

\section{Statement of Purpose}

This paper endeavours to showcase the similarities between the two main characters of the main text. As, they play together and are best friends (even brothers as revealed later), but they are from different social and religious backgrounds. This study examines these two characters through the lens of the Freudian concept of doppelganger as presented in The Uncanny. Doppelgangers are two characters with extreme similarities like Heimlich and Unheimlich.

\section{Research Questions}

- How does the feature of the two chief personalities of the Kite Runner do portrays them doppelganger siblings of each other?

\section{Significance of the Study}

This research attempts to analyse the similarities between the two main characters of The Kite Runner. It will contribute to the long tradition of doppelganger literature: The Picture of Dorian Gray, The Strange Case of Dr. Jekyll, and Mr. Hyde, and Frankenstein. As doppelganger theory is used in the light of The Uncanny to study The Kite Runner.

\section{LITERATURE REVIEW}

The research works that have been conducted on the novel: The Kite Runner are related to cultural, moral, religious, social, and ethnic aspects of the novel. The relationship of Amir and Hassan as brothers has also been worked upon and relationships, in general, have been discussed. The psychological nature of guilt, betrayal, and redemption as well as sexual abuse are studied (Albala, 2014).

In the light of studies done by Ali Can, Hiqma Nur Agustina, Juan Du, Hesham Khadawardi, Karam Nayebpour, David Jafferess, Akram Sadat Hosseini, et al, AjengPancar Tamara et al and Muhammad Asghar Malik et al, this research paper establishes Amir and Hassan as doppelgangers of each other (O'Brien, 2018). This paper takes Amir as Heimlich as he is a socially accepted character. He is from majority ethnical and sectarian groups and he is a powerful character who is from an aristocratic family. While Hassan is Unheimlich because he is a poor and powerless character and he is from minority ethnical and sectarian groups (Neyebpour. 2018).

The research works that have been conducted on the novel: The Kite Runner are related to cultural, moral, religious, social, and ethnic aspects of the novel. The relationship of Amir and Hassan as brothers has also been worked upon and relationships, in general, have been discussed. The psychological nature of guilt, betrayal, and redemption as well as sexual abuse are studied (Edwards \& Vranken, 2018). This chapter will discuss the works of other researchers to find the gaps for this research. Jozef Perelberg (2019) claims that “The Kite Runner describes Amir and Hassan's social class as the background of the story. Both of them have a different social class although they spent their time together". Amir and Hassan play together during their childhood (Jain, 2017). They like the same activities for their pastimes: kite flying, playing cards, and watching Western movies. This article portrays Amir as Heimlich and Hassan as Unheimlich characters as it shows their friendship along with their different social backgrounds. Weber (2019) quotes that: "Amir and Hassan grow up together and they complete each other with their skills. They act like one person together and it is possible to say that their identities fuse".

So, when Amir betrays Hassan, he betrays his own cultural identity as Afghan (Hosseini \& Zohdi, 2016). Due to which he has a problem developing a transnational identity as he does not identify himself with his homeland and has embraced his host land, America, to be able to forget his birthplace and his sin, betrayal (Islam, 2012). This article portrays Amir as Heimlich and Hassan as Unheimlich because as it is Amir who is a more socially accepted character. It also shows Amir's betrayal as uncanny as it prevents him to develop a transnational identity. Agustina (2015) examines the brotherhood reality and identity development in The Kite Runner. She claims that the brotherhood relationship between Amir-Hassan and Amir-Sohrab are the main focus of the text. Amir and Hassan are very close during childhood even when they don't know that they are brothers. Their father loves both his sons equally but as he cannot acknowledge his illegitimate son, Hassan, he sometimes is very harsh to his legitimate son, Amir. Making Amir jealous of Hassan. And, Amir and Hassan have different social backgrounds despite being sons of the same father. Thus, this article establishes Amir as Heimlich as he is the socially accepted son of his father and Hassan as Unheimlich as he is not accepted socially by his father. Khan (2017) studies translingual metaphors in all of Khaled Hosseini's novels: The Kite Runner, A Thousand Splendid Suns, and And the Mountains Echoed. Hosseini like other south Asian writers makes use of his native language metaphors while writing in the English language (Khan, 2017). He uses metaphors of Persian, Pashto, Arabic, and Urdu languages in the novel. Many of the sentences seem like they are directly translated from his native language. So, it is purely linguistic research. It has nothing against the doppelganger theory, nor it has anything to 
support our theory. Hosseini \& Zohdi (2016) describe racism and ethnic prejudice as the reason for the problems that Amir and Hassan face. Afghan society is divided into many ethnic groups for power game (Malik et al., 2013). Malik et al. (2013) claim that: "In the novel, Amir and Hassan are represented as the two opposite pillars of the same society; the wealthy and the poor, Sunni and Shi'a, Pashtun and Hazara, powerful and the feeble". Amir is from the majority ethnic group (Pashtun) due to which he is a Heimlich character while Hassan being from a minority ethnic group (Hazara) is Unheimlich as Pashtuns are politically strong while Hazaras are the slave of the Pashtun masters (Jain, 2017). Khadawardi (2017) examines guilt, redemption, and atonement in The Kite Runner. As, Amir does not help Hassan when he is being sexually harassed, so he has a feeling of guilt. Due to his guilt, he is unable to sleep at night. Amir's guilt torments him even when he becomes a successful writer in America (Albala, 2014). His happy and normal life is affected by the memories of his guilt. He tries to atone for his sin by making Hassan punish him. But Hassan willingly forgives him which makes him more desperate for redemption and atonement because he thinks that he deserves punishment (Wahyudi, 2016).

This all shows Amir's uncanny and what he suffers due to the uncanny feelings he experiences. Jain (2017) discusses the self-actualization of the main character, Amir, in The Kite Runner. Amir spends his childhood in Kabul, Afghanistan. His best friend was Hassan. Amir and Hassan spend their time playing together. When Hassan gets sexually harassed by Assef, the main antagonist of the text, Amir does not help him. This betrayal shows the selfish side of Amir as he does it to acquire his father's affection which he thinks he can get by bringing two kites home. Even when Amir was being selfish, Hassan was always selfless and loyal to Amir (Khadawardi, 2017). As Jain (2017) says: "he, who like a mirror, helped Amir find out his weaknesses in his character". Thus, it provides the similarities and differences in the characters of Amir and Hassan. And helps understand Amir's uncanny through the self-actualization process. Malik et al. (2013) examine how linguistic devices represent ethnicity in The Kite Runner. "The writer presents Amir and Hassan as the representatives of different sides of the same society" (Malik et al, 2013). Amir is from a rich family (Aubry,2009). He belongs to the majority sectarian group: Sunni and majority ethnical group: Pashtun. And, he is a powerful character as he is from a rich family and majority sectarian and ethnic groups (Saputri, 2018). Thus, Amir is the Heimlich character. While Hassan is poor. He belongs to a minority sectarian group: Shi'a and a minority ethnic group: Hazara. Hassan is a powerless character due to belonging to minority groups and being a servant of Amir. So, he is an Unheimlich character (Jefferess, 2009). Nayebpour (2018) studies the storytelling in The Kite Runner. Nayebpour claims that storytelling in the text plays two roles: storytelling helps Amir atone with his past and it explains how Amir's experience affected his adult life. Thus, Amir's narration shows how after betraying Hassan, Amir feels guilt and remorse for the pain he caused (Tamara, 2013). Amir's psychological struggle: his craving for punishment, sympathy with Soraya, and his constantly thinking about Hassan. This all shows the uncanny feeling experienced by Amir and he tried to redeem himself due to the uncanny he experienced (Haholt, 2018). Jefferess (2009) in "To be good (again): The Kite Runner as an allegory of global ethics" claims that The Kite Runner is the allegory of good manners. It talks about universal humanitarian practices shown in the novel. Amir's friendship with Hassan and, after he betrays Hassan, trying to be good again. Amir's act of taking Hassan's son, Sohrab in as his redemption. It develops the uncanny of Amir and his attempts at redemption due to the uncanny. This paper takes Amir as Heimlich as he is a socially accepted character. He is from majority ethnical and sectarian groups and he is a powerful character who is from an aristocratic family (Malik \& Murtaza, 2013). While Hassan is Unheimlich because he is a poor and powerless character and he is from minority ethnical and sectarian groups.

\section{METHODOLOGY}

This study is qualitative in nature. The primary source is Khaled Hosseini's The Kite Runner. The secondary sources concern articles and journals about The Kite Runner. The data is analysed through close textual analysis while focusing on the concept of doppelganger as presented by Sigmund Freud in The Uncanny. This research applies the Freudian doppelgangers of the main characters of The Kite Runner: Amir and Hassan. This research applies the doppelganger as presented in Freud's The Uncanny. Doppelgangers are two characters with the same face, characteristics, or situation. This section will discuss the background of the doppelganger theory and its application to the primary text. People in ancient times until the Victorian period used to believe in the real existence of doppelgangers which come to warn about their double's distress. Otto Rank is one of the first researchers who gave psychological explanations for this process.

Sigmund Freud in The Uncanny gives psychological reasoning for it. Masschelein (2011), a German writer, first coined the word doppelganger in his novel Siebenkas (1796). In the novel, Siebenkas, the main character, and his doppelganger, Leibgeber, are an exact copy of each other. They dress alike, have the same pleasures, and have studied the same sciences. Siebenkas and Leibgeber even exchange their names. There is constant confusion between the main two characters which emphasize the motif of doppelganger (Rank, 1989). So, doppelgangers are look-alikes which cannot be distinguished from one another easily and are a cause of confusion constantly. Along with looks, they can have the same style and same habits. Jean-Paul named this concept but it is a centuries-old concept that has roots in ancient myths and folklore of many ancient civilizations (Masschelein, 2011). A man's shadow was considered to be his guardian spirit. Any shadow damage will cause harm to the man himself (Rank, 1989). In some of those myths, the spirit double of a living person is the announcer of his or her death. Catherine Crowe in The Night-Side of Nature (1848) writes about this kind of supernatural double. Crowe believes that doppelganger is a supernatural phenomenon that takes place to warn 
about the loved one's death or their distress (Heholt, 2018). It was believed that doppelganger is a real phenomenon that can occur to anyone. And, these guardian spirits come to announce their double's death or their grief.

Rank (1989) is one of the first critics who studied doppelganger according to the principles of psychoanalysis. According to Rank, the narcissistic feeling of a person becomes the "double." But when the person stops being narcissistic, it becomes his death. Rank (1989) explains that most of the stories with doppelganger show failed love. Thus, the inability of the main character to love another person. So, the excessive self-love of a person becomes their doppelganger. This excessive self-love makes a person unable to love another person. But when this self-love ends so does life. Masschelein (2011) says that Freud in The Uncanny gives the concept of doppelganger according to psychology. He gives the concept of "Heimlich" and "Unheimlich;" where Heimlich means similar, known, and homely while Unheimlich means different, unknown, and unhomely. Freud describes that the uncanny is the amalgamation of Heimlich and Unheimlich. He further examines the connotative meaning of the word "Heimlich" which is hidden, secretive, and mysterious. Thus, the connotative meaning of Heimlich becomes the same as its opposite Unheimlich. Thus, through the meanings of Heimlich and Unheimlich, he explains how Heimlich is different yet similar to Unheimlich.

He uses "double" as an element of the uncanny in which two characters having the same faces, names, education, or any other character trait or one character's double personalities cause element of the uncanny in the mind of the person experiencing it. Double/doppelganger are two very similar characters. Doppelganger is extracted from The Uncanny as the characters are taken as Heimlich and Unheimlich characters which are similar and opposite people. They have many character traits in common. In this research, the Freudian concept of doppelganger will be applied to Khaled Hosseini's novel: The Kite Runner.

This research attempts to apply the above theory to the text. As, the uncanny and doppelganger is the amalgamation of Heimlich and Unheimlich. So, one of the two main characters is taken as Heimlich while the other character is taken as Unheimlich. Heimlich is known and mysterious at the same time. While Unheimlich is the unknown, mysterious and unhomely.

This research applies doppelganger theory on aristocratic Amir and lower-class Hassan while referring to the abovementioned doppelganger characters. Amir is shown as a rich and respected boy in society. He can go to a good school in the city, but this luxurious life does not bring him any happiness due to a lack of attention from his father. Just like Dorian's aristocratic lifestyle and beauty makes him respectable even when he is spiritually corrupt. While the poverty of Hassan makes him the object of ridicule by street bullies. Even his best friend Amir does not think he is anything more than a servant.

This study examines how Amir and Hassan have the same interests. They read stories together. They play together: cards, kite flying, and climbing trees. They both like watching western movies. But still being so different that Hassan believes Amir is his best friend while Amir considers Hassan not more than a servant. So, Hassan is the loyal one like the monster in Frankenstein while Amir like Dr. Frankenstein is the disloyal one. This research highlights the characteristics that showcase Amir and Hassan as doppelgangers of each other with the help of Freud's theory The Uncanny.

\section{FINDINGS AND DISCUSSION}

This research attempts to highlight the doppelganger characteristics of Amir and Hassan. Doppelgangers are two characters that like mirror image have some similar characteristics but still has some differences as left of the person is the right of the image. According to Freud, doppelganger characters like Heimlich and Unheimlich characters are very similar with little to nothing to differentiate them. Riaz et al. (2018) claims that Amir and Hassan are friends. Amir flies the kites while Hassan is a kite runner. So, they complete each other with their skills and act like one person. Aspects of the text that highlight this tendency are ethnicity, sectarian groups, social class, friendship, and brotherhood. Amir and Hassan are half-brothers, but they are so different. As they are from different ethnical groups: Amir is Pashtun while Hassan is Hazara. This difference makes Amir who belongs to the majority Pashtun group respected in the society while Hassan who is from the minority Hazara group must face bullying from the neighbourhood bullies. Another element of the text that hints at Amir and Hassan being doppelgangers are their sectarian groups: Amir is a Sunni Muslim while Hassan is a Shi'a. Social class difference is another major reason for this research: Amir is the son of a successful merchant while Hassan is the son of Amir's servant (Wahyudi, 2016).

The social status of Dorian Gray, Dr. Frankenstein, and Dr. Jekyll has a great effect on their character being a Heimlich character. Amir is from the upper class while Hassan is from the lower class. The difference in social class is clearly shown in the text through the description of their houses and by the fact that Hassan is the son of Amir's father's servant, Ali. Amir's house is described in the text as: "A broad entryway flanked by rosebushes led to the sprawling house of marble floors and wide windows. Intricate mosaic tiles, handpicked by Baba in Isfahan, covered the floors of the four bathrooms. Gold-stitched tapestries, which Baba had bought in Calcutta, lined the walls; a crystal chandelier hung from the vaulted ceiling" (Hosseini, 2003). This description of the house of Amir shows that it was a very big house. And, his father was rich enough to be able to travel to different countries to bring tiles from Iran and gold tapestries from India (Tamara, 2013). While Hassan lives in a "mud hut" as in the text: "On the south end of the garden, in the shadows of a 
loquat tree, was the servants' home, a modest little mud hut where Hassan lived with his father" (osseini, 2003). The "mud hut" and "servants' home" shows the lower class and poverty of Hassan as it shows that Hassan was a servant at Amir's home. As Akram Sadat Hosseini and Esmaeil Zohdi claim that Amir and Hassan are shown as the two opposite sides of the same society where one is rich and the other is poor (Hossaini \& Zohdi, 2016). This makes upper-class Amir Heimlich like aristocratic Dorian Gray is Heimlich and lower-class Hassan Unheimlich like the distorted picture of Dorian Gray. Doppelgangers have some common traits while some characteristics are opposite to each other so Amir and Hassan being from the same society while depicting different social classes are each other's doppelgangers (Malik \& Murtaza, 2013).

The sectarian groups also influence their Heimlich and Unheimlich roles. Sunni Muslims are in the majority group of Afghanistan while Shi'a Muslims are in minority. Minority Shi'a Muslims are considered religiously fickle by the majority Sunni group. It is proved by an incident in the text when Amir finds a chapter on Hazaras in a history book written by an Irani author. He shows the book to his teacher and the response of the teacher shows that he disapproves of the Shi'a Muslims (Malik \& Murtaza., 2013). As, in the text, the teacher says: "That's the one thing Shi'a people do well,' he said, picking up his papers, 'passing themselves as martyrs.' He wrinkled his nose when he said the word Shi'a like it was some kind of disease" (Hosseini 2003). This shows that the Afghan society considers Shi'a Muslims as bad people who always try to look innocent. The teacher was so biased against them that he wrinkled his nose in disgust and hatred. Akram Sadat Hosseini and Esmaeil Zohdi claim that: "Pashtuns were Sunni Muslims and the minority Hazaras were Shi'a Muslims. This subject alone made Hazaras more secluded in society and for this reason, they sometimes were offended by Sunni Muslims of Afghanistan" (Hossaini, 2003). As Hazaras are Shi'a so they are targeted by Sunni Muslims. They are offended and harassed constantly. This makes Sunni Amir respected in the society while Shi'a Hassan must face the society's discrimination. So, the respected Sunni Amir is Heimlich like respected (Khan, 2017).

Dr. Frankenstein while mocked by society, Shi'a Hassan is Unheimlich like the monster. As, Amir and Hassan are Muslims but belong to different sectarian groups, so they are doppelgangers of each other.

Friendship is also affected by the societal status and influence of society. Amir and Hassan are friends during their childhood. They have the same interests: climbing trees, watching western movies, flying kites, and reading stories. As in the text: "Hassan and I [Amir] used to climb the poplar trees in the driveway of my father's house and annoy our neighbours by reflecting sunlight into their homes with a shard of the mirror" (Hosseini 2003). Amir and Hassan both like climbing trees while playing and used to annoy their neighbours. They also love to watch western movies: "We saw Rio Bravo three times, but we saw our favourite Western, The Magnificent Seven, thirteen times" (Hosseini, 2003). Amir and Hassan liked watching Western movies so much that they had watched them three to thirteen times instead of just once. Though Amir and Hassan play together but are from different backgrounds (Aubry, 2009). As, it is stated in the novel that: "when the sun dropped low behind the hills and we were done playing for the day, Hassan and I [Amir] parted ways. I [Amir] went past the rosebushes to Baba's mansion, Hassan to the mud shack” (Hosseini, 2003). So, even when they play together, they are from different social backgrounds. As "Baba's mansion" shows that Amir's father was a rich man who lived in a big house (mansion). While Hassan was a poor boy because he lives in a "mud shack" as his family did not have enough money to buy a regular house. "They like spending time together. Their favourite pastime activities are seeing movies, flying kites, and reading stories from old Afghan tales. Even though Hassan is a loyal friend, Amir has complicated feelings for Hassan" (Husseini,2003). Amir and Hassan are good friends who like spending time together. They like the same kind of pastime activities. But due to their social class difference that makes Hassan, Amir's servant, Amir does not consider Hassan as his friend even though Hassan is a loyal friend to Amir. So, due to these reasons, the aristocratic Amir becomes Heimlich and the lower-class Hassan becomes Unheimlich. Heimlich and Unheimlich characters combine to form doppelgangers as Dorian Gray and his picture became each other's doppelgangers so Amir and Hassan are each other's doppelgangers (Khan,2017).

There is a great effect of being motherless figures on the personalities of the main characters. Amir and Hassan are living in the same circumstances where they are living with their fathers alone as they have lost their mothers. But the process by which they lost their mothers is so different in accord with society's moral standards. Amir's mother died when he was born while Hassan's mother ran away. In the text: "my [Amir's] mother haemorrhaged to death during childbirth, Hassan lost his less than a week after he was born. Lost her to a fate most Afghans considered far worse than death: She ran off with a clan of travelling singers and dancers" (Hosseini 2003). Amir's mother had died due to the loss of blood during Amir's birth while Hassan's mother ran away from home after a week of his birth. According to Afghan culture, running away from a woman (wife, daughter, or sister) is worse than her dying. Though both women are presented in the text as beautiful Amir's mother, Sofia Akrami was royalty, well-educated, and a teacher at university while Hassan's mother, Sanaubar, was considered a “notoriously unscrupulous woman” (Hossaini, 2003). Even these women present the ideals of the society and determine the main characters' positions in the society. Amir's mother being from the Afghan royalty makes him Heimlich (Hosseini, 2016). Just like Dorian Gray's aristocratic lifestyle made him Heimlich. While elopement of Hassan's mother makes him Unheimlich even when he has nothing to do with it. Society does not accept the elopement of his mother and he must face discrimination at the hands of society. Amir and Hassan are living the same life without their mothers, but Amir's mother is a well-respected woman while Hassan's mother is not respected by society, so they are doppelgangers of each other. 
The fathers of Amir and Hassan are also shown in the text as representatives of their ethnic group, sectarian group, and social class. Like Amir and Hassan, their fathers were also playmates during childhood. But they are so different in adulthood (Agustina, 2015). Amir's father is a successful merchant. He moulds the world according to his likings and is well-respected for his charity work. Amir's father is a powerful man. In the text: "My [Amir's] father was a force of nature, a towering Pashtun specimen with a thick beard, a wayward crop of curly brown hair as unruly as the man himself, hands that looked capable of uprooting a willow tree, and a black glare that would 'drop the devil to his knees begging for mercy" (Hosseini,2003). Amir's father is shown as a stereotypical Pashtun man who is powerful as he is "Capable of uprooting a willow tree" and rich. While Hassan's father is their servant, he is weak and has polio. It is mentioned in the text that: "Ali had a congenital paralysis of his lower facial muscles....... Polio had left Ali with a twisted, atrophied right leg that was sallow skin over bone with little in between except a paper-thin layer of muscle" (Hosseini,2003). Thus, Ali's congenital paralysis and polio show his lower class and lack of power in society. So, Amir, the son of a powerful father, is Heimlich like powerful Dr. Frankenstein who had the power to create a monster while Hassan, the son of a weak father, is Unheimlich like the monster created by Dr. Frankenstein. Amir and Hassan are doppelgangers because they are both living with their fathers, but Amir's father is powerful while Hassan's father is weak.

Brotherhood and morality play an important role to establish the characters. Amir and Hassan are half-brothers as it is later revealed. They are sons of the same father. Even then Hassan is loyal to Amir, Amir is not. On the contrary, Amir is jealous of Hassan. Whenever their father shows some affection towards Hassan, Amir would feel jealous (Edwards \& Vranken, 2018). Hassan was brave and athletic while Amir was a coward. Whenever Amir was teased by the neighbourhood boys, Hassan helped him by fending them off. When Assef, the neighbourhood bully, threatened to beat Amir, Hassan defended Amir with his slingshot. But when Hassan get sexually harassed by Assef, Amir does nothing to save Hassan and quietly lets Assef do it. Ajeng Pancar Tamara and Muhammad Rifqi claim that: "Amir is described as an anxious person. It can be seen by his body response such clenching up when he saw Assef and his gang trapped Hassan in the alley" (Hossaini, 2003). Amir was so afraid of Assef when he saw that Assef has cornered Hassan that his whole body clenched. So, Hassan is loyal to Amir as Frankenstein's monster is loyal to Dr. Frankenstein. Thus, it makes Hassan Unheimlich like Frankenstein's monster. Amir on the other hand is disloyal and coward like Dr. Frankenstein who is disloyal to his creation. Thus, it makes him Heimlich. Amir and Hassan are half-brothers, but Hassan is brave and always stands up to protect Amir while Amir is a coward who does not help Hassan and he is also jealous of Hassan. Thus, Amir and Hassan are each other's doppelgangers because even though they are half-brothers, Amir is a coward and disloyal towards Hassan while Hassan is very brave and loyal to Amir (Jain, 2017).

Amir and Hassan are friends but belong to different social, ethnic, and sectarian groups. Amir belongs to the upper class. He is from the majority Pashtun group. And, he belongs to the majority Sunni Muslim group. Thus, Amir becomes respectable in society. Hassan, on the other hand, is from the lower class. He is from the minority Hazara group and he belongs to the minority Shi'a Muslim group. So, he is bullied by neighbourhood bullies. It makes respectable Amir Heimlich and unrespectable Hassan Unheimlich (Saputri, 2018). Thus, they are each other's doppelgangers as they are friends, but Amir is respectable while Hassan is not. Amir and Hassan are also living in the same circumstances where they are living without their mothers, but Amir's mother had died while Hassan's mother ran away when he a week old. Their fathers also determine their role as Heimlich and Unheimlich. As, Amir's father is a respectable and powerful man while Hassan's father is a weak man with no respect in society (Islam, 2012). So, Amir is Heimlich and Hassan is Unheimlich. Thus, Amir and Hassan are each other's doppelgangers as they are both living with just their fathers, but Amir's father is powerful while Hassan's father is weak. Later, it is revealed that Amir and Hassan are half-brothers. Hassan is brave while Amir is a coward. So, Amir and Hassan are doppelgangers of each other as they are half-brothers while Hassan is brave, but Amir is a coward. In The Picture of Dorian Gray, the picture ages and deforms while Dorian Gray remains young and beautiful. Just like that Hassan gets punished whenever Amir sins. So, Amir and Hassan are doppelgangers just like Dorian Gray and his picture. In Frankenstein, Frankenstein's monster always appears to disturb some important moment of Dr. Frankenstein's life (Khadawardi, 2017). In accord, memories of Hassan, after his sexual harassment, always distress Amir during the happiest moments of his life. Making Amir and Hassan each other's doppelgangers like Dr. Frankenstein and his monster. Thus, these arguments prove that Amir is Heimlich and Hassan is Unheimlich. And, they are each other's doppelgangers.

\section{CONCLUSION}

This study has highlighted that Amir and Hassan as doppelgangers of each other. They are two characters who have some common character traits and some are different characteristics like a mirror image. Amir and Hassan have many common traits that play a role in proving them as each other's doppelgangers. Friendship, brotherhood, and being motherless figures are some important elements that prove them to be doppelganger characters. Amir and Hassan are friends who share similar activities: kite running, playing cards, watching Western movies, and climbing trees. But even though Hassan is loyal to Amir, Amir is disloyal to Hassan and considers him only his servant. Like Frankenstein's monster is loyal to its creator but Dr. Frankenstein is not loyal to his creation. Thus, Amir is Heimlich while Hassan is Unheimlich. Amir and Hassan are each other's doppelgangers as they have the same interests, but Hassan is loyal to his friend while Amir is not. 


\section{LIMITATION AND STUDY FORWARD}

This research focuses on the selected novel through the lens of Freudian doppelganger. The similarities between the main characters: Amir and Hassan are studied in the novel while focusing on friendship, brotherhood, social status, ethnic group, and religious hierarchy. This study only focuses on those themes that are necessary to discuss while studying Freud's doppelganger in The Uncanny, but there are other themes too in this novel, which needs to be discussed in further studies.

\section{ACKNOWLEDGEMENT}

The credit goes to the writers solely as the work is done by their creativity.

\section{AUTHORS CONTRIBUTION}

Introduction and data collection is done by the first author, analysis and conclusion are done by the second author and third author, the fourth author did literature review and formatting.

\section{REFERENCES}

1. Agustina, H. N. (2015). The kite runner: My passion of literature. In International conference on Social Sciences and Humanities (ICSSH'15), 5-6 May 2015, Bali, Indonesia, 43-46.

2. Albala, R. (2014). Towards an Ethics of Post-9/11 Fiction: A Reading of Ian McEwan's Saturday, Don DeLillo's Falling Man, and Mohsin Hamid's The Reluctant Fundamentalist (Doctoral dissertation, Royal Holloway, University of London).

3. Aubry, T. (2009). Afghanistan Meets the" Amazon": Reading" The Kite Runner" in America. PMLA, 25-43. https://doi.org/10.1632/pmla.2009.124.1.25

4. Edwards, E. J., \& Vranken, T. (2018). "Oscar Wilde's Book": Early American Reviews of The Picture of Dorian Gray. PMLA/Publications of the Modern Language Association of America, 133(1), 199-204. https://doi.org/10.1632/pmla.2018.133.1.199

5. Heholt, R. (2018). 'Powerful beyond all question': Catherine Crowe's Novels of the 1840s. In British Women's Writing from Brontë to Bloomsbury, 1, 39-51. Palgrave Macmillan, Cham. https://doi.org/10.1007/978-3-31978226-3_3

6. Hosseini, K. (2003). The kite runner. Penguin.

7. Hosseini, A. S., \& Zohdi, E. (2016). The kite runner and the problem of racism and ethnicity. International Letters of Social and Humanistic Sciences, 74, 33-40. https://doi.org/10.18052/www.scipress.com/ILSHS.74.33

8. Islam, S. (2012). Representation of political islam in recent fiction with particular reference to john updikes terrorist, pamuks snow (Doctoral dissertation, Aligarh Muslim University).

9. Jain, J. (2017). Diaspora Writes Home. Springer. https://doi.org/10.1007/978-981-10-4846-3

10. Jefferess, D. (2009). To be good (again): The Kite Runner as allegory of global ethics. Journal of Postcolonial Writing, 45(4), 389-400. https://doi.org/10.1080/17449850903273572

11. Jozef Perelberg, R. (2019). Passion and melancholia, red and black: The vicissitudes of the sexual in an analytic process. The International Journal of Psychoanalysis, 100(6), 1237-1247. https://doi.org/10.1080/00207578.2 $\underline{019.1672504}$

12. Kamm, F. A. (2019). 'There'sa Ghost in My House': The Female Gothic and the Supernatural in What Lies Beneath (2000). In Gender and Contemporary Horror in Film. Emerald Publishing Limited. https://doi.org/10.1108/978-1-78769-897-020191010

13. Khadawardi, H. (2017). Superego Guilt, Redemption and Atonement in Khaled Hosseini's the Kite Runner. International Journal of Humanities Social Sciences and Education (IJHSSE), 4(2), 88-99. https://doi.org/10.20431/2349-0381.0402009

14. Khan, A. W. (2017). Metaphors with Translingual Dimensions in the Novels of Khaled Hosseini. AWEJ for translation \& Literary Studies, 1(4), 160-175. https://doi.org/10.24093/awejtls/vol1no4.13

15. Malik, M. A., \& Murtaza, G. (2013). The levels of Power relationship in The kite Runner. Journal of Literature, Languages and Linguistics, 1, 71-77.

16. Malik, M. A., Shah, S. K., \& Mahmood, R. (2013). The role of linguistic devices in representing ethnicity in The Kite Runner. International Journal of Linguistics, 5(1), 161-175. https://doi.org/10.5296/ijl.v5i1.3303

17. Murshida, A. A. (2017). Khaled Hosseini's the Kite Runner: A Critical Discourse Analysis (Doctoral dissertation).

18. Masschelein, A. (2011). The unconcept: The Freudian uncanny in late-twentieth-century theory. Suny Press.

19. Nayebpour, K. (2018). The Uses of Storytelling in Khaled Hosseini's The Kite Runner. Hacettepe Üniversitesi Edebiyat Fakültesi Dergisi, 35(1), 52-60. https://doi.org/10.32600/huefd.434221

20. O'Brien, S. (2018). Translating Trauma in Khaled Hosseini's The Kite Runner. Transnational Literature, 10(2), 1-A5.

21. Rahimy, T. (2017). Politics of Flight: A Philosophical Refuge. Erasmus University Rotterdam. Retrieved from http://hdl.handle.net/1765/103266

22. Rank, O. (1989). The Double: A Psychoanalytical Study, trans. Harry Tucker, Jr. London: Karnac. 
23. Riaz, A., Nasreen, Z., \& Zaman, F. (Eds.). (2018). Political Violence in South Asia. Routledge. https://doi.org/10.4324/9781351118224

24. Saputri, E. (2018). BEING AN AFGHAN MAN: Masculinity in the Novel Kite Runner (Doctoral dissertation, Universitas Pendidikan Indonesia).

25. Shelley, M. W. (2012). The Annotated Frankenstein. Harvard University Press.

26. Tamara, A. P. (2013). Amir's Anxiety and Motive in Khaled Hosseini's The Kite Runner. Semarang: Humanities Dian Nuswantoro Univerty Semarang.

27. Wahyudi, A. (2016). Cultural Untranslatability Words In The Novel And The Mountains Echoed By Khaled Hosseini. (Thesis) http://repository.uinjkt.ac.id/dspace/bitstream/123456789/31937/3/AHMAD\%20WAHY UDI-FAH.pdf

28. Weber, C. P. (2019). Narrating (against) the Uncanny: Goethe's" Ballade" versus Hoffmann's Der Sandmann. Goethe Yearbook, 26(1), 79-100.

29. Winthaegen, J. J. A. (2015). Duality of Human Nature during the Fin de Siecle. https://doi.org/10.1 353/gyr.2019.0035

30. Weedman, D. (2014). Men, Monsters and Morality: Shaping Ethics through the Sublime and Uncanny. Capstone, Pacific University. 